\title{
Danube water-economy plans stir up environmental opposition
}

\section{London}

LAST August, when the USSR Supreme Soviet and Central Committee of the Communist Party cancelled the 'project of the century' - the diversion southwards of the north-flowing rivers of Russia and Siberia - the decision gave impetus to the growing campaign for the cancellation of another, less-publicized watermanagement project, the DanubeDnieper irrigation canal. The canal, together with auxiliary works including two hydroelectric stations on the lower Dnieper, is known as VHK, the Ukrainian acronym for 'water-economy complex'. But there are growing fears among Ukrainian scientists that VHK may prove a false economy.

Addressing the Soviet Academy of Sciences recently, the president of the Ukranian academy, Academician Borys Paton, claimed that preliminary estimates put the construction costs at more than 30,000 million rubles and that the canal would also create "negative ecological consequences" including the cutting off of estuaries from the sea, the need to install expensive and sophisticated technology to purify the waters of the Danube, the flooding of vast tracts of agricultural land, and the problem of rendering harmless 5 or $6 \mathrm{~km}^{3}$ (presumably annually) of highly mineralized drainage run-off. An expert commission of the USSR State Planning Commission has demanded a revision of the plans, which have not been formally ratified. But, Paton said, "most regrettably, as happens in our country", the preliminary work has already started.

The main purpose of VHK is to develop the agricultural potential of southern Ukraine and Moldavia. Paton himself is highly critical of current Soviet investment policy in land improvement, which, he told a special session of the Ukrainian academy last year, spends a disproportionate amount on irrigation, to the detriment of anti-erosion and anti-acidification work, desalination and the like.

The use of Danube water for irrigation, in the opinion of the anti-VHK lobby, could cause considerable damage both to agriculture and the river-estuary coastal ecosystem. Ironically, the Kiliya channel, the northernmost arm of the Danube delta, from which the proposed canal would presumably start, is now being developed as a nature reserve of unique ecological significance.

Although the Danube is an international waterway, there is at present no international body responsible for water quality. The Danube Commission, established in 1948 by the Danube Convention which the Ukrainian SSR signed as a sep- arate state (the Moldavian SSR was represented by the Central Soviet government) is concerned only with problems of navigation, and thus only with pollution resulting from ships. There is, so far, no international body responsible for land-based pollution, although much Central European industry is situated along the Danube. In December 1985, a meeting of representatives of the riparian countries was convened in Bucharest to discuss a unified environmental strategy for the river, but this produced little more than a preliminary statement of intent. The opponents of VHK say that the scheme could ruin the "recreational natural resources" of the Ukrainian republic, in which there has been considerable investment in recent years, while, according to Professor B.P. Zahoruyko, rector of the Odessa Maritime Fleet Engineers' Institute, the project could cause "no little harm" to river transport and fisheries. Zahoruyko is particularly alarmed at the proposal to isolate the Dniester estuary and the BelgorodDnestrovskii harbour from the Black Sea by a dam.

Whether the protests of the Ukrainian scientists will be as effective as those of the Russians may eventually depend on what factors really decided the cancellation of the north-south diversion. According to Academician Aleksandr Yanshin, a vicepresident of the Soviet Academy of Sciences, the decision was made on strict scientific criteria; suggestions that public concern over the environmental consequences played a significant part are "a long way from the truth". Less official conversations with Soviet academicians, including ecologists, suggest that protests from the representatives of the humanities within the academy and from the group of Russian writers known collectively as the the 'villagers' may have helped to sharpen the issues for the experts who took the final decision.

In Ukraine, however, the writers have been less concerned with environmental issues, and so were soundly scolded during the Congress of Ukrainian Writers last summer by the first secretary of the board of the Ukrainian Writers' Union, Pavlo Zahrebelnyy. They should emulate the "boldness" of their Russian colleagues, he urged, and speak up against the "senseless planning" that is inflicting such harm on the environment. If the Ukrainian writers and representatives of the humanities fail to respond to Zahrebelnyy's call, then the ultimate decision on the Danube-Dnieper VHK may well indicate what part public pressure from concerned individuals really played in the cancellation of the northsouth diversion.

Vera Rich

\section{Biotechnology firm turning the corner?}

\section{London}

Celltech, Britain's only major biotechnology company, together with its two associated companies, threatens to show its first profit in the coming financial year. Although the dominant patent position of Genentech has forced Celltech to stop its development of tumour necrosis factor as a human thereapeutic product, the company is optimistic about gaining a share of the market for tissue plasminogen activator, as it believes that the patent position outside the United States is still open.

Reporting a turnover of $£ 7.6$ million with a loss of $£ 0.7$ million for the financial year that ended in September 1986, Celltech emphasized that it remains the world leader in bulk production of monoclonal antibodies, which account for most of the $£ 5$ million product sales of Celltech, Boots-Celltech and Apcel last year. Hopes run high for sales of a monoclonalantibody-based test of ovulation. Measuring the ratio of two urinary metabolites of oestrogen and progesterone, the test is expected to become available in infertility clinics within months. But, in collaboration with London International, BootsCelltech hopes to develop a dipstick-like version of the test to be sold over the counter as an anti-conception aid.

Celltech's chief executive, Gerard Fairtlough, placed particular emphasis last week on two relatively new projects. One is the development of the tissue inhibitor of metalloproteinases as a therapeutic substance. The inhibitor is part of the natural mechanism by which the turnover of connective tissues is controlled and is expected to be useful in the therapy of rheumatoid arthritis and other connective tissue disorders.

The other highlighted project combines Celltech's recombinant DNA and monoclonal antibody expertise. Financed by American Cynamid to the tune of $£ 5$ million over two years, it is aimed at cancer detection and treatment with genetically tailored antibodies to tumours, complexed to toxins, drugs or radionuclides.

In a report on Celltech released this month, stockbrokers Wood Mackenzie place the company within the top ten in the world in terms of revenues and describe it as a "robust competitor". Celltech is likely to develop very rapidly over the next three years, says the report, and should be in a position to offer its shares to the public "in 1987 or 1988 "; Gerard Fairtlough concurs, adding that any decision to go public will depend on the state of the market and the needs of the company and its shareholders.
Peter Newmark 